\title{
3rd International Conference on
}

\section{MANAGEMENT, ECONOMICS \& FINANCE}

\author{
26-28 February, 2021
}

\section{Factors Affecting the Decision in Using Mobile Banking}

\author{
Kitimaporn Choochote \\ Faculty of Interdisciplinary Studies, Khon Kaen University, Thailand
}

\begin{abstract}
This research aims to study factors affecting the decision in using mobile banking services for a case study of Kathu District Phuket by using questionnaires as a tool for data collection with 400 samples. Findings in the study reveal that majority of people for 167 persons select to use the service of Siam Commercial Bank accounting for $41.8 \%$. The reason for selecting the financial transaction via mobile banking is due to inconvenience in using the services at the bank branches as commented by 232 people accounting for 58.0\%. While 198 persons, accounting for 49.5 percent can learn how to use mobile banking through 198 bank employees. As for frequency in using mobile banking, most of the sample about 248 people use the service at an average of 2-5 times accounting for $62.0 \%$. The problem and barrier in using mobile banking services are a transaction security issueม and for the satisfaction with the rate of the fee charged in each transaction. If the suggestion of usage is provided by staff, this will make users more interested in using mobile banking services.
\end{abstract}

Keywords: e-commerce, e-banking, decision making, iBanking, mobile banking service

\section{Introduction}

Advancements in telecommunications and communication technologies have affected financial and banking operations. While commercial banks currently are more competitive, banking and finance business, therefore, need to be improved and developed to offer novel services suitable for the changing era by using technology to improve the operation to be capable of offering services that meet customer needs and facilitate financial transactions. Particularly, the use of Mobile Banking is a form of financial transaction on the smart-phone that the bank utilizes to increase the channels on earning revenue and expanding its customer base. While it helps maintain market share and also helps reduce operating costs, which will result in a competitive advantage in the business and also improve the bank's potential.

Adding channels of financial transaction services via the internet of the commercial banks in various forms either via the website or the application on a smart-phone will help the bank to increase channels of revenue generation, expand the customer base, maintain market share and also help reduce operating costs. This will result in the commercial banks to offer services via 


\section{3rd International Conference on}

\section{MANAGEMENT, ECONOMICS \& FINANCE}

\section{6-28 February, 2021}

the internet to take a competitive advantage in their business operations and to also improve service efficiency.

Banking services through mobile banking have become another new alternative for current banking customers because the development of internet communication technology provides convenience, fast and effective accessibility via various communication devices easily and it does not take a very long time. Therefore, this makes financial transactions via the internet become completely different from traditional financial transactions. And the rate of using mobile banking services tends to increase continuously. This is because it is a convenient way for customers to perform financial transactions via the internet by themselves. It is like having a private online bank to access financial transactions anywhere, anytime, 24 hours a day, which is a new marketing service channel where service providers will be able to generate income from servicing from among individual customers, business-to-business customers, and business entrepreneurs with consumers. Due to these reasons, the researcher is interested in studying the factors that influence the decision to use mobile banking services.

\section{Literature Review}

\subsection{Decision Making}

Decision making is a process in solving organizational problems by seeking and choosing for alternatives or best practices to achieve the defined objectives of the organization. Therefore, it can be said that the decision making is the conclusion or the final result of the rational thinking process so that to select the right actions suitable for the situation, the resource, and the individuals, to be able to implement and achieve the desired goals and objectives.

Decision making is an integral part of the roles of the executive resulting from position and authority. It is the role of entrepreneur, disturbance handler, resource allocator and negotiator.

\subsection{Theory of Acceptance Model}

Theory of Acceptance Model: TAM is a model for predicting acceptance and usage of technology in the workplace. It is a recognized and well-known theory that is the performance indicator of technology usage as proposed by Davis, which is additionally modified from the Theory of Reasoned Action: TRA to develop into a TAM model and to study in the context of acceptance for the use of information systems by not considering the norms of the surrounding people, and behaviours to be used as factors in predicting actual usage behaviours.

Users will accept this technology only if there are factors that influence decision making to accept TAM technology. 


\title{
3rd International Conference on
}

\section{MANAGEMENT, ECONOMICS \& FINANCE}

\author{
26-28 February, 2021
}

Figure 1: Technology Acceptance Model (Davis, 1989)

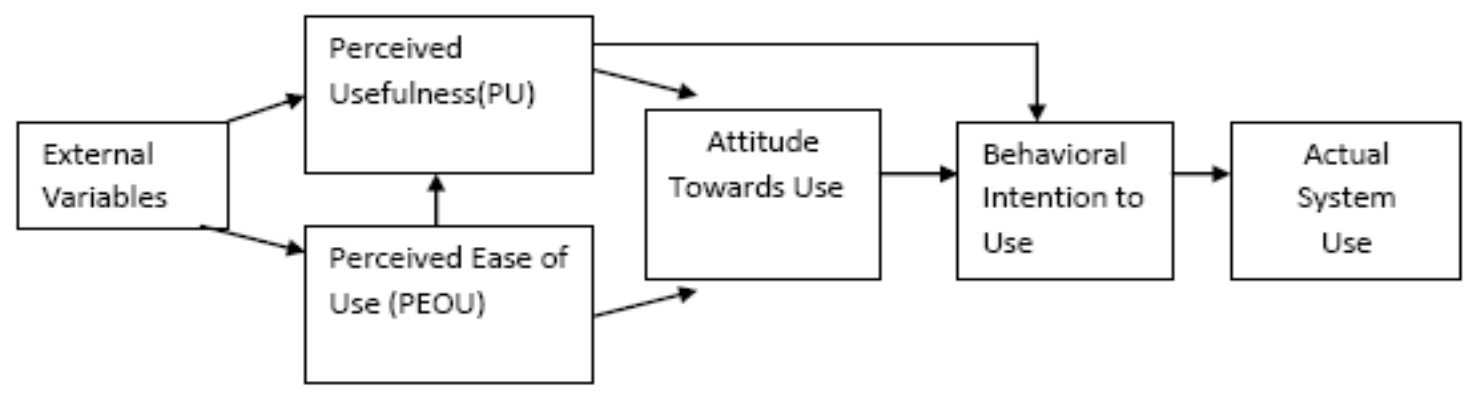

- External Variables refer to the influences of external variables that will create awareness for each individual which include experiences, beliefs, knowledge, understanding, and motivation to encourage users to see values to have demand for such high-value services

- Perceived Usefulness (PU) refers to awareness in the usage of technology to obtain benefits either obtaining advantages of technology such as reduction in operation steps, time-saving, or fast and efficient operation

- Perceived Ease of Use (PEOU) refers to the perception in the usage of technology that makes the operation easier from the original manual operation which may cause delays or obstacles. And after the technology is introduced, the operation becomes faster and more efficient.

- Attitude Towards Use refers to a positive attitude to the usage caused by the user's understanding towards the benefits of technology which is based on the ideas in making use of technology by people who recognize in the benefits

- Behavioural Intention to Use refers to the intent of use which indicates the recognition behaviour in the acceptance of technology of each person.

- Actual System Use is a result of technology adoption and actual utilization

\subsection{Mobile Banking}

Mobile refers to mobile phones and banking refers to banking which has an exact definition and when taken together, it means Mobile Banking incorporated with the Internet Banking: iBanking. Since the past, we started to know and use it in the form of iBanking via PC or Desktop computer. In this era, mobile phones or smartphones play a large role in our daily lives instead, making the service of iBanking follow us everywhere. Until in this era that we have a truly Mobile Banking because of the design and development whether security system or various features that support the use on various platforms available on the Smartphone. In which the original i-Banking system with a shortened version of user and password identification is 


\section{3rd International Conference on}

\section{MANAGEMENT, ECONOMICS \& FINANCE}

\section{6-28 February, 2021}

introduced to be used on mobile phones. There is also the other type developed to be superior to the original iBanking that supports especially for mobile phone use, with a PIN Code system to increase security both of which are all working on the Mobile Banking platform.

\subsection{P's marketing mix}

4P's marketing mix is a marketing stimulus that leads to buying decisions which can be divided as follows; the product that will allow consumers to buy, and price. When consumers evaluate the options and make decisions, the price will affect buying behaviour. Distribution channel (place); Marketers need to prepare products ready for distribution since this will influence the purchase decision. Marketing promotion; every process of consumer purchasing decisions can be influenced by marketing promotion.

\section{Research Framework}

Figure 2: Research Framework

\begin{tabular}{l} 
Demographic data \\
- Gender \\
- age \\
- occupation \\
- monthly income \\
- Education level \\
\hline
\end{tabular}

The decision to use the mobile banking service

- Types of financial transaction use

- Decision to use Mobile Banking

- Source of usage information Mobile Banking

- Learning Mobile Banking Services

Factors Affecting the Decision in Using Mobile Banking Service

- People around you use Mobile Banking.

- Frequency of using Mobile Banking 


\section{3rd International Conference on}

\section{MANAGEMENT, ECONOMICS \& FINANCE}

\section{6-28 February, 2021}

\begin{tabular}{|l|} 
4P's marketing mix \\
— product \\
- price \\
- place \\
- promotion
\end{tabular}

\section{Research Objectives}

1. To study the factors that influences the selection of mobile banking services of the people in Kathu District

2. To study the selection of mobile banking services for people in Kathu district.

\section{Research Methodology}

The study population consists of people living in Kathu District, Phuket province divided into 13,133 men, 15,108 women and a total of 28,241 people. The sample used in this study is the population of 400 people living in Kathu District. Phuket Province. The calculation of sample size is conducted and the formula to find the size of the sample with a known population is used where confidence value of $95 \%$ and the error of not more than 5\% are defined according to Taro Yamane's formula (1967).

Since the calculation results in the population to contain 394.41 samples, however, to obtain the comprehensive data and the minimum response rate of with the confidence that makes all estimators free from bias, the researcher, therefore, adds some more 6 samples into this study to make data obtained from the samples to meet the specified size. Therefore, the samples that the researcher used to analyse contain a total of 400 people.

In this study, the researcher verifies all questionnaires for completeness of the questionnaires and processes coding in the questionnaire then analyses and processes data using statistical software using the descriptive statistical calculations as the basic statistics used to describe the characteristics of the sample. The values for analysing consist Percentage, Mean, Standard Deviation, and Relationship between independent and dependent variables.

\section{Conclusion}

General data of the respondents consist of 206 males accounting for 51.5 percent. The age range of respondents is between 25 - 30 years accounting for 48.0 percent. The educational level of respondents includes 224 bachelor degree graduates accounting for $56.0 \%$. The majority of respondents of 224 are private employees accounting for $34.0 \%$. The average monthly income of 224 people ranges between 10,001 - 20,000 baht, representing 45.2\%. Most 


\section{3rd International Conference on}

\section{MANAGEMENT, ECONOMICS \& FINANCE}

\section{6-28 February, 2021}

of the samples consisting of 167 people representing $41.8 \%$ choose to use the services of Siam Commercial Bank. While 232 respondents, representing $58.0 \%$ provide reasons in choosing to use financial transactions via mobile banking that it is because of the inconvenience of using services in person at the bank branches. About 198 respondents representing 49.5\% learn how to use mobile banking with bank employees. As for the frequency of using mobile banking, most respondents of 248 people accounting for $62.0 \%$ use averagely 2-5 times.

As for marketing mix factors influencing the decision making of customers in using mobile banking service, the results reveal that, in term of product, most of the sample gives the highest priority when choosing to use financial services via mobile banking that meets the needs of the respondents with an average value of 4.43. In terms of price, most of the samples give the highest priority for pricing without any annual fee in using the service, with an average value of 4.45. Regarding the distribution channel, the samples provide the highest priority where the use of mobile banking services can be available in all locations in Thailand with an average value of 4.50. In terms of marketing promotion, the samples provide the highest priority if the staffs provide the suggestion on how to use the service which will make respondents more interested in using the service, with an average value of 4.51 .

\section{Discussion}

Factors influencing the decision to use mobile banking services, the results reveal that in the selection of mobile banking services, most samples receive advice and learn from bank employees since it is not convenient for customers to use the service at the bank branches.

For marketing mix factors, most of the samples are satisfied with the appearance and sufficient application. The calculation of the annual fee for using the service is appropriate.

\section{Suggestion for Entrepreneurs}

For entrepreneurs, credibility, and security of mobile banking, most users are still not confident in the security of mobile banking. Therefore, the bank should provide staffs to give advice or build credibility for customers which will result in increased service usage.

In each financial transaction, fee collection is not yet satisfied by customers. Therefore, the bank should adjust a fee rate according to the increased trend of transactions via mobile banking.

\section{References}

Archana S, Vineet K. 2012. Mobile Banking as Technology Adoption and Challenges: A Case of M-Banking in India. International Journal of Scientific and Research. Vol 2 (2). 


\section{3rd International Conference on}

\section{MANAGEMENT, ECONOMICS \& FINANCE}

\section{6-28 February, 2021}

S.Karnouskos, "Mobile Payment: A journey through existing procedures \&standardization initiatives " IEEE Communications Surveys \& Tutorials, pp.44-66, 2004.

Tan, M. \& Teo, T. S. H. 2000. Factors influencing the adoption of Internet banking. Journal of the Association for Information Systems. Vol. 1 (5), pp.1-42.

Jayawardhena, C. \& Foley, P. 2000. Changes in the banking sector - the case of Internet banking in the UK. Internet Research: Electronic Networking Applications and Policy. Vol. 10 (1), 19-30.

Gamoorthy Avinanya, S. A. 2012. Mobile Banking - An Analysis. Asian journal of research in banking and finance, 2 (7).

Thomas L. Saaty. 2008. Decision making with the analytic hierarchy process. Int. J. Services Sciences, Vol. 1 (1), pp. 83-98.

Miric, Milan and Lu, Jinhing and Teodoridis, Florenta, Decision-Making Skills in an AI World: Lessons from Online Chess (February 15, 2020). Available: https://ssrn. com / abstract = 3538840 or http://dx.doi.org/ 10.2139/ssrn.3538840.

Predicting Users' Continuance Intention Toward E-payment System: An Extension of the Technology Acceptance Model - Scientific Figure on ResearchGate. Available: https:// www.researchgate.net/figure/The-original-technology-acceptance-model-TAM-Davis1989_fig1_265905915 [accessed 17 Apr, 2020].

Neil Charness and Walter R. Boot. 2016. Chapter 20. Technology, Gaming, and Social Networking. Technology Use and Age. Handbook of the Psychology of Aging, Eighth edition. Available: http://scitechconnect.elsevier.com /wp- content/uploads/ 2016/ 04/ Tech nology-Gaming.pdf [accessed 17 Apr, 2020].

Taneja Vikas, P. S. 2011. Mobile Banking and Economics Development. In p. s. taneja vikas, E-banking and e-commerce (p. 205). alfa publication.

Eusebio, S. and Stuart J, Barnes. 2004. M-banking services in Japan: A strategic perspective. International Journal of Mobile Communications. Vol 2(1), pp. 51-66.

Koenig- Lewis, N., Palmer, A. and Moll, A. 2010, "Predicting young consumers' take up of mobile banking services", International Journal of Bank Marketing, Vol. 28 No. 5, pp. 410432. Available: https://doi.org/10.1108/026523210110 64917.

E. Constantinides. 2006. The Marketing Mix Revisited: Towards the 21st Century Marketing, Journal of Marketing Management, 22:3-4, 407-438, DOI: 10.1362/02672570677686119 0 . 